CZASOPISMO INŻYNIERII LĄDOWEJ, ŚRODOWISKA I ARCHITEKTURY JOURNAL OF CIVIL ENGINEERING, ENVIRONMENT AND ARCHITECTURE

JCEEA, t. XXXIII, z. 63 (3/16), lipiec-wrzesień 2016, s. 271-278

\author{
Przemysław MARKIEWICZ ${ }^{1}$
}

\title{
ZINTEGROWANE PROJEKTOWANIE ENERGETYCZNE BUDYNKÓW ENERGOOSZCZĘDNYCH
}

\begin{abstract}
Projektowanie budynków energooszczędnych staje się powszechną koniecznością, wynikającą ze względów środowiskowych, ekonomicznych i społecznych oraz z obowiązującego prawa.

$\mathrm{Na}$ ostateczny poziom zużycia energii końcowej w budynku wpływa wiele wzajemnie uzupełniających się i współzależnych, rozwiązań architektonicznobudowlanych i instalacyjnych, które powinny być zweryfikowane odpowiednimi analizami i symulacjami wydajności energetycznej na możliwie wczesnym etapie projektowania. Im więcej takich rozwiązań zostanie zastosowanych, tym ostateczne parametry energetyczne budynku będą lepsze. Projektowanie budynków energooszczędnych wymaga w związku $\mathrm{z}$ tym reorganizacji procesu projektowego w kierunku tzw. Zintegrowanego Projektowania Energetycznego. Wiąże się to z koniecznością zastosowania odpowiednich narzędzi wspomagających projektowanie i przesunięcia głównego ciężaru decyzji projektowych na jak najwcześniejszy etap prac. Te narzędzia to oprogramowanie w standardzie BIM, powiązane z programami umożliwiającymi przeprowadzenie dla wirtualnego modelu budynku szeregu symulacji jego wydajności energetycznej.
\end{abstract}

Słowa kluczowe: modelowanie informacji o budynku, model energetyczny budynku, analizy wydajności energetycznej, zużycie energii końcowej

\section{Wprowadzenie}

Projektowanie budynków w standardzie energooszczędnym już wkrótce nie będzie ekskluzywną alternatywą dla znacznie mniej wymagających budynków normatywnych, lecz powszechną koniecznością, wynikającą ze względów środowiskowych, ekonomicznych i społecznych oraz z obowiązującego prawa.

Projektowanie budynków energooszczędnych jest trudne, gdyż są to budynki zaawansowane technicznie, wymagające przemyślanego powiązania rozwiązań architektonicznych i architektoniczno-budowlanych z rozwiązaniami

\footnotetext{
${ }^{1}$ Przemysław Markiewicz, Politechnika Krakowska, Wydział Architektury, Instytut Projektowania Budowlanego A-4, Katedra Budownictwa Ogólnego i Materiałów Budowlanych A-41, ul. Podchorążych 1, 30-084 Kraków; tel. 601-414-240; markiewiczprzem@gmail.com
} 
instalacyjnymi oraz przeprowadzenia szczegółowych symulacji i obliczeń ich efektywności energetycznej. Praktycznie wszystkie rozwiązania projektowe, rekomendowane dla budynków energooszczędnych różnią się znacznie od dotychczasowych, powszechnie stosowanych rozwiązań standardowych. Zdeterminowane nadrzędnym problemem energooszczędności zmieniają się zasady kształtowania otoczenia, bryły budynku i układu funkcjonalnego, a zestaw energooszczędnych komponentów architektoniczno-budowlanych, z których składa się budynek, staje się w dużym stopniu współzależny od przyjętych rozwiązań instalacyjnych.

Projektowanie budynków energooszczędnych wymaga reorganizacji procesu projektowego w kierunku tzw. Zintegrowanego Projektowania Energetycznego [1], w którym szczególnie ważna jest wczesna faza projektowania oraz wprowadzenie odpowiednich narzędzi wspomagających projektowanie w postaci specjalistycznego oprogramowania komputerowego.

Zasady i standardy zintegrowanego projektowania energetycznego, wdrażane są już m.in. w Austrii, Francji, Wielkiej Brytanii i w Niemczech [2] a przez nieuchronną konieczność radykalnego zwiększenia efektywności energetycznej w sektorze budownictwa, wkrótce staną się powszechną europejską normą.

\section{Opis procedury badawczej}

\subsection{Modelowanie informacji o budynku - BIM}

BIM (ang. Building Information Modeling) [3] to w dosłownym przekładzie ,modelowanie informacji o budynku”, co oznacza tworzenie, przy pomocy odpowiedniego oprogramowania, ogromnej bazy danych, dokładnie definiującej każdą część budynku (konstrukcję, materiały i ich właściwości, wyposażenie, itp.) i uporządkowanej w trójwymiarowej przestrzeni w postaci wirtualnego modelu 3D. Projekt w standardzie BIM powstaje przy użyciu trójwymiarowych obiektów, takich jak ściany, stropy, dachy, sufity, okna, drzwi, itd., którym, poza wymiarami geometrycznymi, nadawane są odpowiednie parametry (właściwości fizyczne, techniczne, itp.). Integracja informacji w ramach jednej bazy danych umożliwia automatyczną identyfikację wprowadzanych zmian i rozpoznanie ewentualnych kolizji.

Zaprojektowanie budynku jako wirtualnego modelu przestrzennego, w którym wprowadzone są wszystkie parametry rzeczywistego obiektu, takie jak np. warstwy przegród z określonymi materiałami i ich właściwościami fizycznymi, parametrami technicznymi, cenami, itp. pozwala już na wczesnym etapie projektowania na przeprowadzanie różnego typu analiz i symulacji, zupełnie niedostępnych w tradycyjnych projektach, opracowywanych w programach typu CAD-2D (ang. Computer Aided Design) [4], w postaci zestawu płaskich rzutów, przekrojów i elewacji. 
Charakterystycznym wyróżnikiem projektowania w programach wspomagających projektowanie w standardzie BIM jest przesunięcie głównego nakładu pracy na wczesne fazy procesu projektowego (etap koncepcji), dzięki czemu możliwości wpływania na efektywność są największe, przy najniższych kosztach i najmniejszych trudnościach z tym związanych (rys. 1).

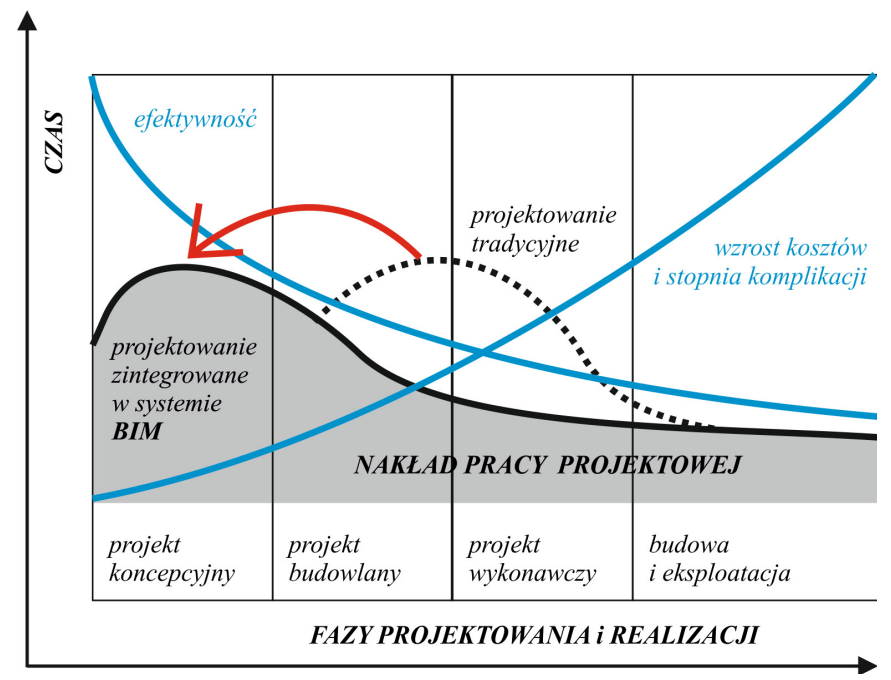

Rys. 1. Porównanie nakładów pracy na różnych etapach projektowania w systemie BIM i CAD-2D

Fig. 1. Comparison of the effort for different phases of designing process in the BIM and CAD-2D

\subsection{Model energetyczny budynku - BEM}

Efektywność energetyczną projektowanego budynku można przetestować już we wczesnej fazie projektowania i na długo przed realizacją i zastosowaniem wszystkich rozwiązań w rzeczywistości, poprzez symulacje określane jako „modelowanie energetyczne". Przeprowadzenie takich symulacji wymaga trójwymiarowego, wirtualnego modelu budynku w standardzie BIM, w którym wszystkie rozwiązania budowlane i instalacyjne są dokładnie sparametryzowane. Kiedy w wirtualnym modelu budynku wprowadzamy dane dotyczące projektowanych temperatur użytkowych, strefowania temperaturowego poszczególnych pomieszczeń, harmonogramów użytkowania, itp. to możemy powiedzieć, że przekształcamy model BIM w tzw. Model Energetyczny Budynku BEM (ang. Building Energy Model) [5].

W Modelu Energetycznym Budynku BEM możemy badać wpływ na efektywność energetyczną różnych wariantów projektowych [6] Model budynku BEM usytuowany jest w konkretnej lokalizacji geograficznej, dla której wykorzystuje się komplet danych meteorologicznych. Poza ilością energii w rozbiciu 
na różne składowe (ogrzewanie, chłodzenie, wentylacja) i różne nośniki energii, można analizować komfort cieplny (PPD, PMV), badać pracę systemów odzysku energii, itp. Przeprowadzanie różnego typu wariantowych analiz i symulacji umożliwia osiągnięcie optymalnej efektywności energetycznej oraz weryfikację i korekty przyjętych rozwiązań.

\subsection{Zintegrowane Projektowanie Energetyczne - IED}

Metodologia i zasady tzw. Zintegrowanego Projektowania Energetycznego - IED (ang. Integrated Energy Design) stają się standardem nowoczesnego projektowania budynków [7], definiowanym jako:

- proces organizacji prac projektowych z przesunięciem punktu ciężkości na wczesne etapy projektowania, w celu osiągnięcia większej efektywności i zminimalizowania kosztów,

- priorytetowe traktowanie energooszczędnych, zintegrowanych rozwiązań architektonicznych, budowlanych i instalacyjnych,

- ścisła współpraca pomiędzy inwestorem / klientem i przyszłym użytkownikiem a architektem, konsultantami, ekspertami i projektantami branżowymi od samego początku procesu projektowania aż do realizacji.

\section{Budynek referencyjny}

Opracowany przez autora model energooszczędnego budynku referencyjnego to niewielki, jednorodzinny budynek mieszkalny (rys. 2), przewidziany dla potrzeb 4-osobowej rodziny, o łącznej powierzchni użytkowej $171,1 \mathrm{~m}^{2}$.

Budynek ma orientację południową, jest bez podpiwniczenia i posiada użytkowe poddasze podniesione na ściankach kolankowych. W budynku zastosowano rozwiązania architektoniczno-budowlane rekomendowane dla budynków energooszczędnych w standardzie niskoenergetycznym NF40 i pasywnym NF15.

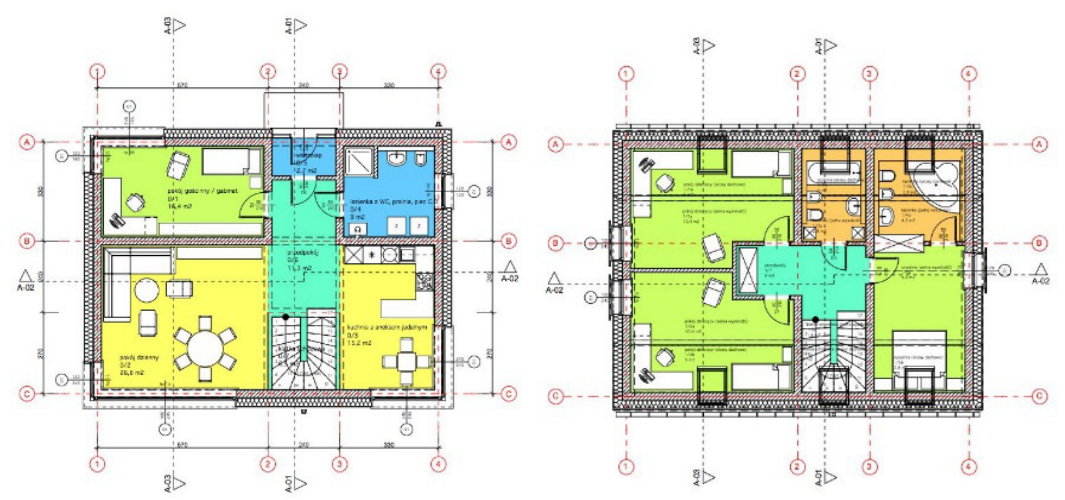

Rys. 2. Program funkcjonalny budynku referencyjnego

Fig. 2. The functional program of the reference building 
Model budynku referencyjnego dzięki zastosowaniu BIM zawiera m.in.:

- dokładnie sparametryzowaną konstrukcję obudowy budynku w postaci struktur warstwowych $\mathrm{z}$ określonymi materiałami budowlanymi wraz z przypisanymi do nich parametrami fizycznymi,

- otwory z określonymi parametrami stolarki okiennej i drzwiowej,

- ważniejsze elementy wewnętrzne, stanowiące znaczącą masę kumulującą ciepło, zróżnicowane jako ciężkie (struktury betonowe), średnie (struktury murowane), lekkie (struktury szkieletowe),

- przyjęty poziom infiltracji powietrza przez przegrody w godzinnym bilansie energetycznym oraz całkowitego przenikania powietrza $(\mathrm{ACH})$ o wartości $1,0\left[\mathrm{l} / \mathrm{s}, \mathrm{m}^{2}\right]$.

Analiza geometryczna modelu utworzona została na podstawie tzw. stref $\mathrm{z}$ określonymi temperaturami użytkowymi, zgrupowanych w tzw. bloki termiczne. Po skonfigurowaniu bloków termicznych (rys. 3), wirtualny model architektoniczny BIM zostaje zmieniony w Model Energetyczny Budynku (BEM).
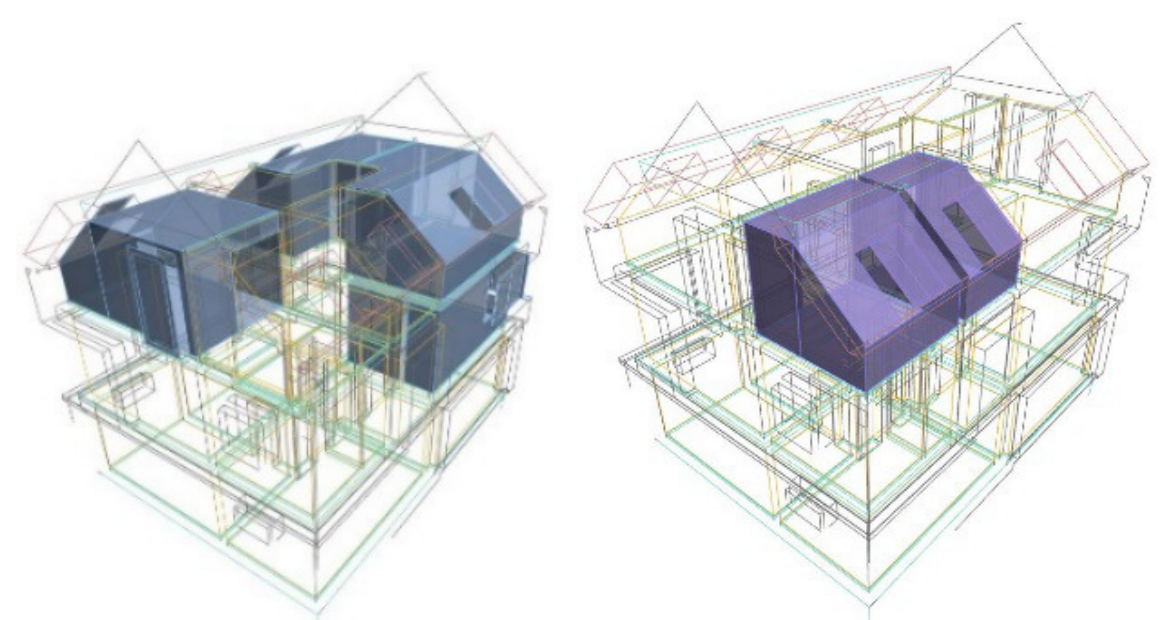

Rys. 3. Bloki termiczne, tworzące użytkową kubaturę budynku referencyjnego

Fig. 3. Thermoblocks, forming a usable volume of the reference building

W projekcie budynku referencyjnego wprowadzono konkretną lokalizację (Kraków) ze ściśle określonymi parametrami środowiska, klimatu i otoczenia.

Do potrzeb oszacowania energetycznego określono ponadto typ instalacji (ogrzewanie, chłodzenie, CWU, wentylacja), źródła energii, profile użytkowania bloków termicznych, itp. parametry mające wpływ na wydajność energetyczną. 


\section{Analizy wydajności energetycznej i poziomu komfortu}

Roczna analiza zużycia energii końcowej dowodzi (rys. 4), że budynek referencyjny jest budynkiem energooszczędnym, charakteryzującym się niskim zużyciem energii na ogrzewanie, na poziomie mieszczącym się pomiędzy wymaganiami stawianymi dla budynków niskoenergetycznych NF40 a dla budynków pasywnych NF15 [8].

Największą ilość energii pozyskiwanej w budynku referencyjnym (rys. 5) zapewniają zyski od słońca. Jest to spowodowane dużą powierzchnię przeszkleń, przypadającą na elewację południową.

W rocznej analizie strat energii należy zwrócić uwagę na relatywnie wysoką wartość strat energii przez wentylację. Należy jednak pamiętać, że jest ona spowodowana stratami energii przez wentylację w lecie, czyli wywiewaniem w porze nocnej nadmiaru ciepła zakumulowanego w budynku w ciągu upalnych dni.

W budynkach energooszczędnych często występujący problem stanowi przegrzewanie wnętrz $\mathrm{w}$ okresie letnim. $\mathrm{Z}$ tego względu analizy energetyczne powinny być uzupełnione odpowiednimi analizami poziomu komfortu, ze szczególnie uważną analizą dla najcieplejszych dni w roku.

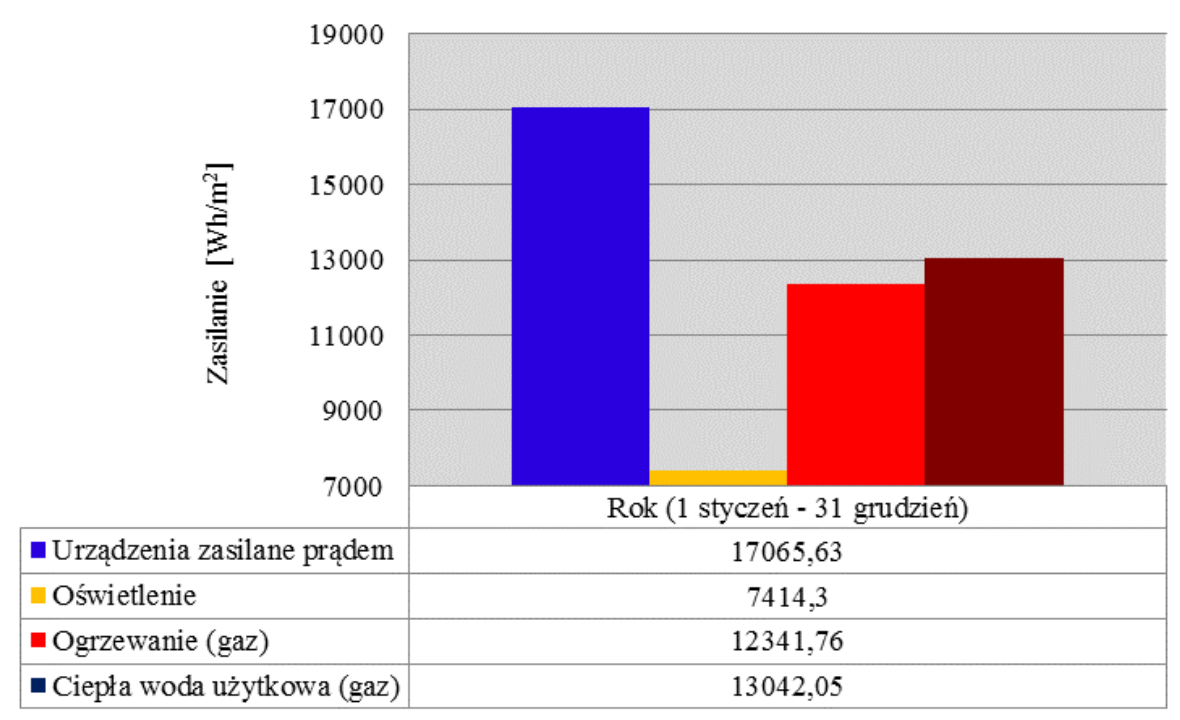

Rys. 4. Zużycie energii końcowej na ogrzewanie

Fig. 4. Final energy consumption for heating 


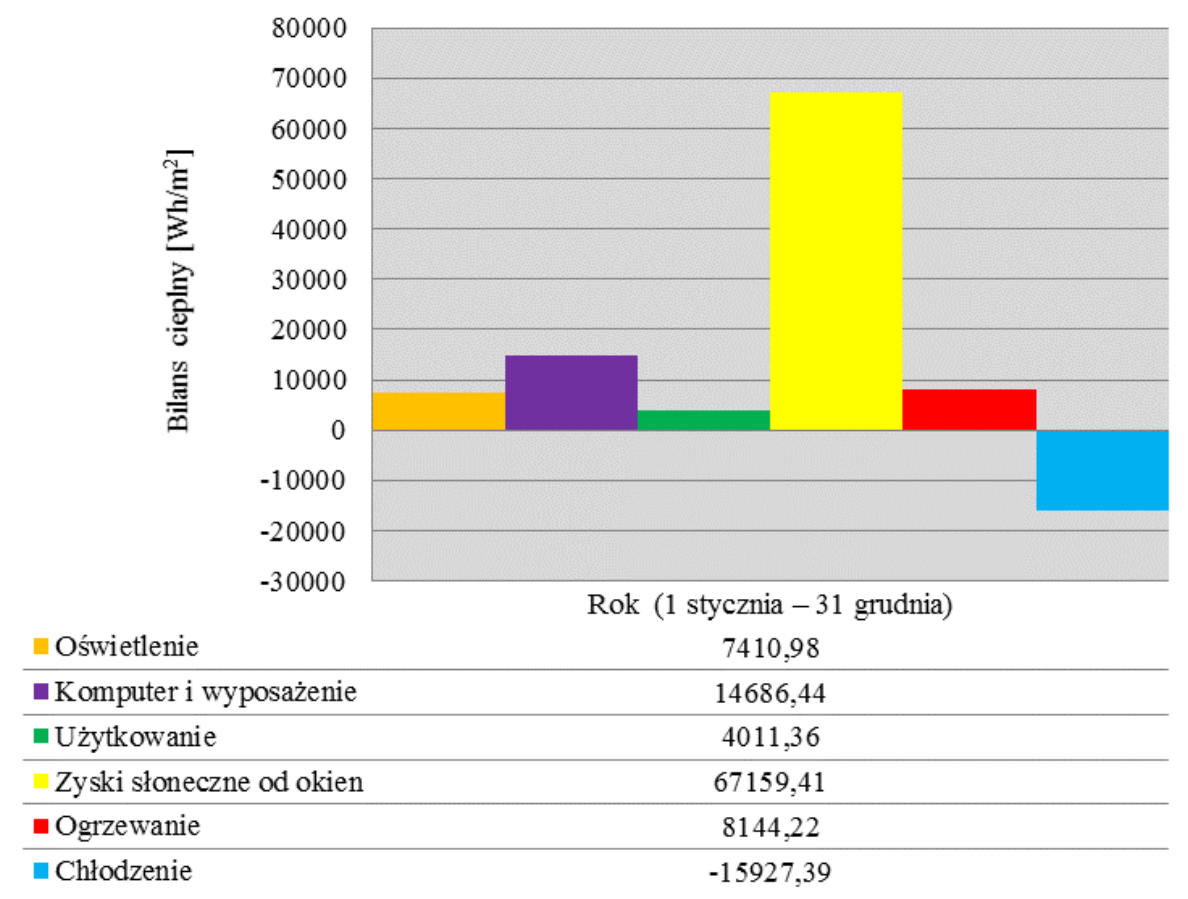

Rys. 5. Zyski wewnętrzne oraz zyski od słońca

Fig. 5. Internal energy profits and gains from the sun

\section{Wnioski}

$\mathrm{Na}$ ostateczny poziom wydajności energetycznej budynku wpływa wiele wzajemnie uzupełniających się i współzależnych, rozwiązań architektonicznobudowlanych, które są rekomendowane dla budynków energooszczędnych. Im więcej takich rozwiązań zostanie zastosowanych w projekcie i podczas realizacji, tym ostateczne parametry energetyczne budynku będą lepsze.

Aby jednak można było zweryfikować projekt budynku pod kątem jego wydajności energetycznej konieczna jest zmiana w podejściu do dotychczasowych zasad projektowania w kierunku Zintegrowanego Projektowania Energetycznego. Wiąże się to $\mathrm{z}$ zastosowaniem odpowiednich narzędzi wspomagających projektowanie. Te narzędzia to po pierwsze oprogramowanie w standardzie BIM, pozwalające na stworzenie wirtualnego, dokładnie sparametryzowanego i zaprogramowanego budynku. Po drugie to odpowiednie oprogramowanie umożliwiające przeprowadzenie dla wirtualnego modelu budynku symulacji wydajności energetycznej, a więc analiz zużycia energii końcowej, zysków i strat energetycznych oraz poziomu komfortu i przegrzewania. 


\section{Literatura}

[1] Nordby A, Przewodnik MaTrID - Zintegrowane projektowanie, European Commission Executive Agency for Competitiveness and Innovation, 2013, str. 3.

[2] Miecznikowski P.: BIM - wybór czy konieczność, [w:] Materiały Budowlane 10/2013(494), str.59.

[3] BIM Curriculum, Graphisoft, 2013, [@:] http://www.graphisoft.com/learning/trainingmaterials/bim-curriculum/ [dostęp: 21.03.2016].

[4] Sydor M.: Wprowadzenie do CAD. Podstawy komputerowo wspomaganego projektowania, Wydawnictwo Naukowe PWN, Warszawa 2009, str.47.

[5] O'Donnell J. , Maile T., Rose C., Transforming BIM to BEM: Generation of Building Geometry for the NASA Ames Sustainability Base BIM, Lawrence Berkeley National Laboratory, 2013, str.8.

[6] What is Energy-modeling and building simulation, [@:] http://energymodels.com/what-is-energy-modeling-building-simulation, [dostęp: 21.03.2016].

[7] Norby A., Integrated Energy Design - some principles of low energy building design, Inteligent Energy Europe, 2009, [@:] http://www.intendesign.com/, [dostęp: 18.03.2016].

[8] Określenie podstawowych wymogów, niezbędnych do osiagnięcia oczekiwanych standardów energetycznych dla budynków mieszkaniowych oraz sposobu weryfikacji projektów i sprawdzenia wykonanych domów energooszczędnych. ETAP I : Wytyczne do weryfikacji projektów budynków mieszkalnych, zgodnych ze standardem NFOSiGW, Krajowa Agencja Poszanowania Energii S.A., Warszawa, 2012.

\section{INTEGRATED ENERGY DESIGN OF AN ENERGY EFFICIENT BUILDINGS}

\section{S u m m a r y}

Designing of a buildings as an energy-efficient buildings is a common necessity, resulting from an environmental, economic and social reasons as well as from the applicable law. The final level of the energy efficiency of the building affected by many complementary and interdependent, architectural and construction solutions that are recommended for energy efficient buildings. If more of such solutions will be used, the final energy performance of the building will be better.

Designing process of the energy efficient buildings requires a reorganization of the design process in the direction of the so-called Integrated Energy Design (IED). This is connected with the need to use appropriate tools to support the designing workshop and shift the main burden of decisions on the earliest design stage. These tools include computer software in a BIM standard and related programs, able to perform for the virtual model of the building a series of simulations of its energy efficiency.

Keywords: Building Information Modeling, Building Energy Model, analysis of energy efficiency, final energy consumption

DOI:10.7862/rb.2016.210

Przestano do redakcji: $17.05 .2016 r$.

Przyjęto do druku: 30.11 .2016 r. 